\title{
The effect of concurrent infections with Pasteurella multocida and Ascaridia galli on free range chickens
}

\author{
C. Dahl ${ }^{\mathrm{a}}$, A. Permin ${ }^{\mathrm{a}, *}$, J.P. Christensen ${ }^{\mathrm{a}}$, M. Bisgaard ${ }^{\mathrm{a}}$, \\ A.P. Muhairwa ${ }^{\mathrm{a}}$, K.M.D. Petersen ${ }^{\mathrm{a}}$, J.S.D. Poulsen ${ }^{\mathrm{b}}$, \\ A.L. Jensen ${ }^{\mathrm{b}}$ \\ ${ }^{a}$ Department of Veterinary Microbiology, The Royal Veterinary and Agricultural University, \\ 4 Stigbøjlen, 1870 Frederiksberg C, Denmark \\ ${ }^{\mathrm{b}}$ Central Laboratory, The Royal Veterinary and Agricultural University, 3 Grønnegårdsvej, \\ 1870 Frederiksberg $C$, Denmark
}

Received 20 August 2001; received in revised form 3 January 2002; accepted 26 January 2002

\begin{abstract}
Pasteurella multocida and Ascaridia galli are observed with high prevalences in free range chickens in Denmark, but the impact is unknown. A study was carried out to examine the interaction between A. galli and P. multocida in chickens and the impact on production.

Five groups, each with 20 18-week-old Lohmann Brown chickens were infected. Group 1 was orally infected with $1000 \pm 50$ embryonated A. galli eggs. Group 2 received $10^{4}$ cfu P. multocida intratracheally. Group 3 was infected with $A$. galli and subsequently with P. multocida. Group 4 was infected with P. multocida followed by A. galli. Group 5 was the control. The study ran for 11 weeks where clinical manifestations, weight gain and egg production were recorded. Excretion of $P$. multocida was determined on individual basis and blood smears were made for differential counts. At the end of the study pathological lesions and the number of adult worms, larvae and eggs in the faeces were recorded.

The birds were more severely affected when infected with both pathogens compared to single infections with A. galli or $P$. multocida, respectively. A lower weight gain and egg production was observed with dual infections. A. galli infection followed by a secondary P. multocida infection resulted in more birds with pathological lesions and continued $P$. multocida excretion.

In conclusion a negative interaction between $A$. galli and P. multocida was observed and it is postulated that free range chickens are at higher risk of being subjected to outbreaks of fowl cholera when they are infected with A. galli. (C) 2002 Elsevier Science B.V. All rights reserved.
\end{abstract}

Keywords: Chicken; Epidemiology; Pasteurella multocida; Ascaridia galli; Concurrent infections; Interactions

\footnotetext{
* Corresponding author. Tel.: +45-3528-3763; fax: +45-3528-3762.

E-mail address: ape@kvl.dk (A. Permin).
} 


\section{Introduction}

During the last five decades commercial poultry production has almost exclusively been based on confined production systems with a high level of biosecurity. However, during the last 10 years consumers have shown an increased interest in products from free range and organic production systems. Table egg production from these systems has increased significantly and now accounts for almost one-third of all table eggs produced in Denmark (Anon., 2000). In contrast to confined production systems in which high levels of biosecurity can be obtained, free range production is characterised by a high risks of acquiring infections. A recent study in Denmark has shown that the flock prevalence of Ascaridia galli is $100 \%$ in free range/organic systems, whereas it is only about $25 \%$ in confined indoor deep litter production systems (Permin et al., 1999). Pasteurella multocida infections are also common in non-confined poultry production systems (Christensen et al., 1999). Recent investigations showed that about $80 \%$ of the diagnosed cases of pasteurellosis in Danish poultry appeared in flocks that had access to outdoor areas (Christensen et al., 1998). Studies on the interactions between A. galli and Escherichia coli in chickens have indicated that subclinical $A$. galli infections, may have an immunosuppressive effect, allowing E. coli to establish itself (Permin et al., 2002). Likewise, a synergistic effect of migrating Ascaris suum larvae and E. coli was observed in piglets (Adedeji et al., 1989) and of salmonellosis on subsequent infections with A. suum in adult swine (Wade and Gaafar, 1981). A similar effect may exist for $P$. multocida infections in A. galli infected flocks. The aim of the present study was to examine interactions between $A$. galli and $P$. multocida and their impact on disease manifestations, weight gain, egg production and excretion of $A$. galli and P. multocida.

\section{Materials and methods}

\subsection{Experimental animals}

One hundred 16-week-old Lohmann Brown female chickens with no history of fowl cholera in previous or present flocks on the farm were used for each experiment. The chickens were randomly distributed into five groups each consisting of 20 individually identified animals. Two weeks before the onset of the study all birds were examined for the presence of $P$. multocida by taking swabs from the cloaca, dissolving the swabs in saline water and subsequently injecting white balb/cJ mice with the solution as described by Muhairwa et al. (2000). Furthermore, a faecal sample from each bird was examined for the presence of parasites using the McMaster concentration techniques (Permin and Hansen, 1998). Regardless of the parasite status all the birds were treated with flubendazole ( $7 \mathrm{mg} /$ $\mathrm{kg}$ live weight per 3 days) to ensure no interference from a low grade parasite infection.

\subsection{Housing}

Each group was placed in a $6 \mathrm{~m}^{2}$ cleaned and disinfected henhouse with nesting boxes and perches. The floor was covered with sawdust. The birds received 11-14 h of light 
(10-15 lux) a day depending on the age of the chickens (Anon., 2001). The birds had free access to water and commercial feed containing 18\% protein (layers mesh).

\subsection{Experimental design}

The experiment was a $2 \times 2+1$ cohort study (Thrusfield, 1995) in which group 1 was infected with $A$. galli, group 2 with $P$. multocida, while groups 3 and 4 were infected with both pathogens but in different orders. The group 5 represented uninfected controls. The study had a duration of 11 weeks.

\subsection{Infections}

A. galli eggs were prepared according to Permin et al. (1997b). A clinical isolate of $P$. multocida, serotype A3 originating from an outbreak of fowl cholera among wild birds was used for inoculation (Christensen et al., 1998). Chickens in group 1 were infected with $1000 \pm 50$ infective $A$. galli eggs orally. In group 2 all birds were infected with $10^{4} \mathrm{cfu} P$. multocida intratracheally. Group 3 was initially infected with $1000 \pm 50$ infective A. galli eggs per bird and 4 days later with $10^{4}$ cfu P. multocida intratracheally. Group 4 was first infected with $10^{4}$ cfu $P$. multocida intratracheally and 4 days later with $1000 \pm 50$ infective A. galli eggs. Group 5 was sham infected orally with normal tap water (Table 1).

\subsection{Parameters}

All groups were observed on a daily basis for clinical signs. Eggs were collected, counted and weighed on a daily basis while the birds were weighed only once a week. Blood samples were taken 1 week before the start of the experiment at the age of 17 weeks and subsequently at the age of 18,21, 24, 28 and 29 weeks. Blood smears for differential counts of the white blood cells were made according to Permin and Hansen (1998). At the age of 20,22, 25 and 28 weeks, swabs were taken from the cloaca and pharynx of each chicken to examine for the presence of $P$. multocida as described by Muhairwa et al. (2000).

At the end of the experiment all surviving birds were killed and subjected to postmortem examinations for pathological changes. From each spleen swabs were streaked onto blood agar plates and checked for growth of $P$. multocida. The intestines were removed to check for the presence of adult and larval forms of $A$. galli. The intestines were

Table 1

Experimental design including group size, infection and infection doses

\begin{tabular}{llll}
\hline Group & Group size & Infection & Dosage \\
\hline 1 & 20 & A. galli & $1000 \pm 50$ eggs \\
2 & 20 & $P$. multocida & $10^{4} \mathrm{cfu}$ \\
3 & 20 & A.galli $+P$. multocida & $1000 \pm 50 \mathrm{eggs}+10^{4} \mathrm{cfu}$ \\
4 & 20 & $P$. multocida + A.galli & $10^{4} \mathrm{cfu}+1000 \pm 50$ eggs \\
5 & 20 & Control & Sham infected with water \\
\hline
\end{tabular}


opened in a longitudinal section and rinsed with water over two sieves, the smallest with a mesh aperture of $38 \mu \mathrm{m}$. The sieve retentate was examined for adult worms and larvae using a stereo microscope at $40 \times$ magnification. Faecal samples were taken from the cloaca and parasite eggs were counted using a concentrated McMaster technique (Permin and Hansen, 1998).

\subsection{Statistical methods}

Data was stored and statistical analyses were carried out using the statistical software program GraphPad Prism ${ }^{\circledR}$ version 3.0 from GraphPad Software (2000). Analysis of variance, chi-square and unpaired $t$-tests were used for normal distributed data. Otherwise a Kruskal-Wallis test was used. The level of significance was set as $p<0.05$.

\section{Results}

\subsection{Pretrial examinations}

The swabbings showed that the birds were free of infections with $P$. multocida. Furthermore, the birds were free of infections with parasites, i.e. A. galli, Heterakis gallinarum and Capillaria spp. (Permin et al., 1999).

\subsection{Clinical signs}

Depression was observed in the birds infected with $P$. multocida, i.e. groups 2-4 during the first week after infection with P. multocida. After inoculation the chickens became quiet and passive and their feathers ruffled. Feed and water consumption were also depressed. The chickens were most affected the first week after the infection, after which an improvement was seen. Differences in clinical signs between groups only infected with P. multocida and groups infected with both P. multocida and A. galli were not observed. Increasing mortality, starting shortly after inoculations with $P$. multocida, was observed for groups 2 (three birds), 3 (six birds) and 4 (three birds) and continued up to 4 weeks after inoculation. These chickens tested positive for P. multocida in spleen and liver when swabs were streaked onto blood agar plates. No indications of clinical disease were observed in groups 1 and 5 .

\subsection{Weight gain}

The average weight gain for all groups are shown in Fig. 1. For groups $2-4$ a drop in weight gain was observed immediately after they had been infected with P. multocida. Both the control group and the $A$. galli group showed weight gains during the whole observation period and had the highest weight gain while the doubly infected groups had the lowest. However, the groups were not easily distinguished from each other. During the first week a significant difference was seen between groups infected with $P$. multocida and groups which had not been infected with bacteria. Groups 1 and 3 were only infected with A. galli 


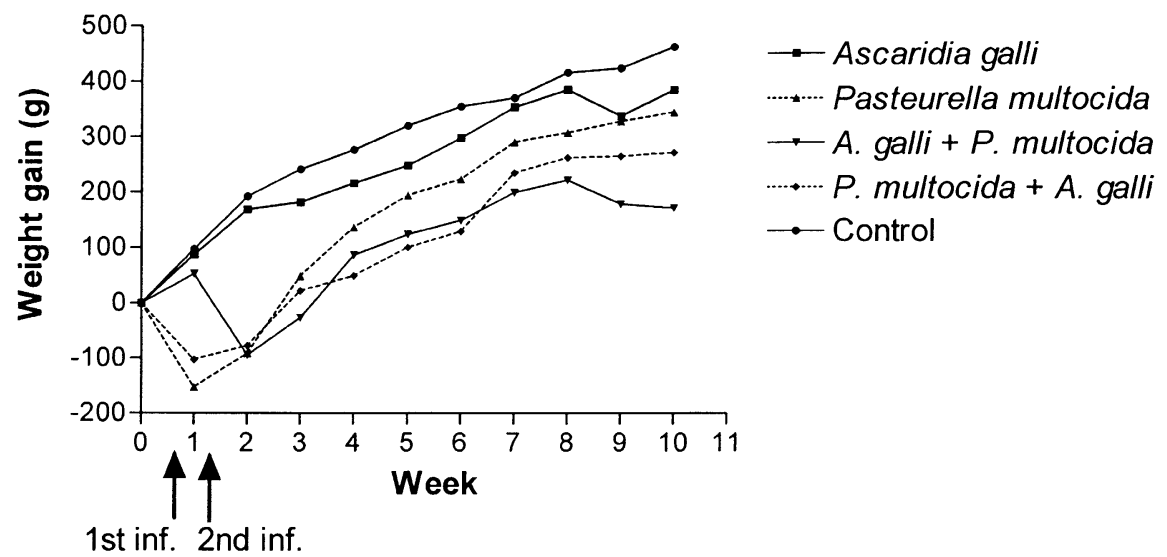

Fig. 1. Weight gain for all five groups $(N=20$ per group) until week 10 .

at this time and could not be separated from the control group $(p>0.05)$. Groups infected with $P$. multocida could not be differentiated from each other at this point of the trial.

During the second week group 3 dropped in the weight gain immediately after infection with $P$. multocida. At this time no significant differences between the three groups infected with $P$. multocida were observed. In the final week a significant difference between the $A$. galli group and the two double infected groups as well as between the control group and the three groups infected with $P$. multocida were observed $(p<0.05)$.

\subsection{Eggs}

All groups started laying within 3 days after the first infection at the age of 18 weeks (Table 2). Differences observed between groups as to the age at start of lay were not significant $(p>0.05)$. However, at the end of the experiment a significant number (at $90 \%$ level) of hens were not in lay in groups 2 (three birds), 3 (six birds) and 4 (three birds) $(p<0.06)$. Significant differences were observed in the numbers of eggs per hen per week for groups 1 and 5 (the A. galli group and the control group) compared to groups 2-4

Table 2

Egg production data for all groups

\begin{tabular}{llllll}
\hline & $\begin{array}{l}\text { Group 1: } \\
\text { A. galli }\end{array}$ & $\begin{array}{l}\text { Group 2: } \\
\text { P. multocida }\end{array}$ & $\begin{array}{l}\text { Group 3: } \\
\text { A.galli } \\
+ \text { P. multocida }\end{array}$ & $\begin{array}{l}\text { Group 4: } \\
P . \text { multocida } \\
+ \text { A. galli }\end{array}$ & $\begin{array}{l}\text { Group 5: } \\
\text { control }\end{array}$ \\
\hline $\begin{array}{l}\text { Age at the first egg in the } \\
\text { group (days) }\end{array}$ & 130 & 130 & 131 & 130 & 132 \\
$\begin{array}{l}\text { Age when all the chickens } \\
\quad \text { were in lay (days) }\end{array}$ & 145 & 158 & 157 & 159 & 143 \\
$\begin{array}{l}\text { Hens remaining at week 29 } \\
\begin{array}{l}\text { Hens in lay of remaining animals } \\
\text { (in \%) at end of trial (week 29) }\end{array}\end{array}$ & 20 & 17 & 14 & 17 & 20 \\
\hline
\end{tabular}

\footnotetext{
* Significantly lower (at 90\% level) compared to other groups $(p<0.06)$.
} 

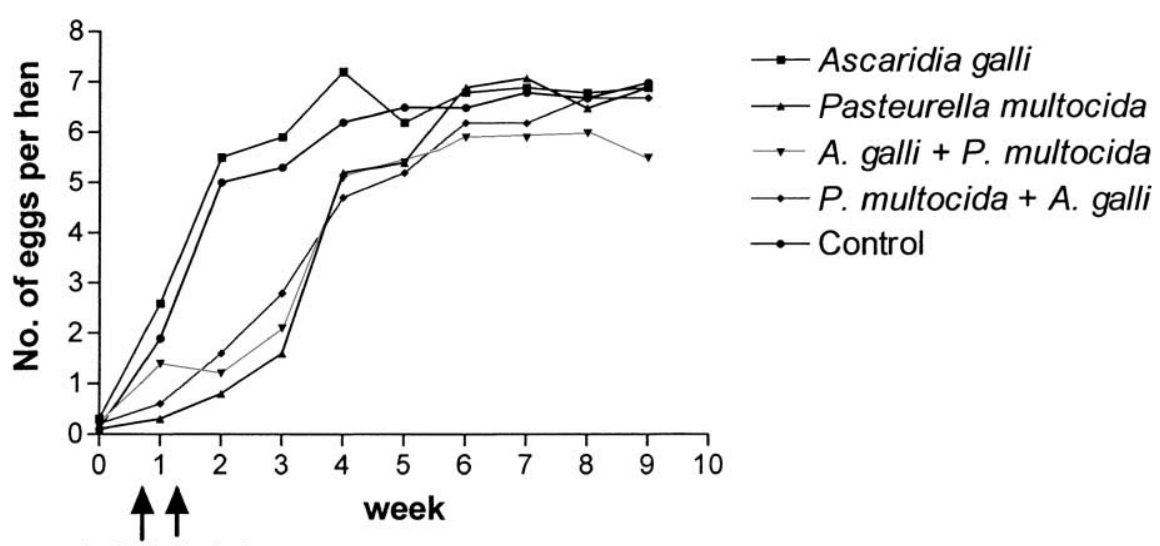

1. inf. 2. inf.

Fig. 2. Number of eggs per hen per week.

infected with $P$. multocida (Fig. 2). Finally, significant differences in single egg weights between groups were not observed during the whole experiment.

\subsection{Differential counts}

Double infected groups had the lowest percentage of lymphocytes. Significant differences between the control group and the A. galli group were not observed. The A. galli group however differed significantly from the double infected groups during the weeks 3, 6 and 10. Significant differences between groups 2 and 3 as well as between the control group and the double infected groups were noticed in week 3 . Statistically significant differences were also seen between groups 2 and 3, 3 and 4 as well as 3 and 5 in week 6 and between groups 4 and 5 in week 10.

Double infected groups had the highest percentage of heterophil granulocytes compared to other groups. A statistical significant difference in per cent heterophil granulocytes was observed between the A. galli group and the control group versus the double infected groups as well as between groups 2 and 3 .

Differences in per cent eosinophilic granulocytes were observed between groups 1 and 4 in first week. At the time of inoculation differences between groups 1-3 and the control group as well as between groups 2 and 4 were observed. In the sixth week group 1 separated itself from the rest of the groups significantly $(p<0.05)$. In the final week there were statistical differences between the A. galli group and groups 2, 4 and 5 as well as between groups 3 and 4.

Basophilic granulocytes and monocytes were only represented in small percentages making it difficult to evaluate the results.

\subsection{Excretion of P. multocida}

The excretion of $P$. multocida in the various groups is given in Table 3. Birds from groups 2 and 3 inoculated with P. multocida and A. galli and P. multocida, respectively, did not 
Table 3

Chickens testing positive for $P$. multocida during experiment

\begin{tabular}{|c|c|c|c|c|c|c|c|c|c|c|}
\hline \multirow[t]{2}{*}{ Week } & \multicolumn{2}{|c|}{$\begin{array}{l}\text { Group 1: } \\
\text { A. } \text { galli }^{\mathrm{a}}\end{array}$} & \multicolumn{2}{|c|}{$\begin{array}{l}\text { Group 2: } \\
\text { P. multocida }\end{array}$} & \multicolumn{2}{|c|}{$\begin{array}{l}\text { Group 3: } \\
\text { A. galli } \\
+ \text { P. multocida }\end{array}$} & \multicolumn{2}{|c|}{$\begin{array}{l}\text { Group 4: } \\
\text { P. multocida } \\
+ \text { A. galli }\end{array}$} & \multicolumn{2}{|c|}{$\begin{array}{l}\text { Group 5: } \\
\text { control }^{\mathrm{a}}\end{array}$} \\
\hline & Pos./all & $\%$ & Pos./all & $\%$ & Pos./all & $\%$ & Pos./all & $\%$ & Pos./all & $\%$ \\
\hline 2 & 37010 & 0 & $9 / 17$ & 53 & $11 / 17$ & $65^{*}$ & $6 / 18$ & 33 & 37010 & 0 \\
\hline 4 & 37010 & 0 & $1 / 17$ & 6 & $1 / 14$ & 7 & $1 / 17$ & 6 & 37010 & 0 \\
\hline 7 & 37010 & 0 & $0 / 17$ & 0 & $1 / 14$ & $7^{*}$ & $0 / 17$ & 0 & 37010 & 0 \\
\hline 10 & 37010 & 0 & $1 / 17$ & 6 & $2 / 14$ & $14^{*}$ & $0 / 17$ & 0 & 37010 & 0 \\
\hline
\end{tabular}

${ }^{a}$ Swabs were taken from four animals and pooled into one sample, i.e. five samples from each group before inoculation into mice.

* Significantly more $(p<0.05)$.

eliminate the infection. Significantly more birds were positive in group 3 infected with both the pathogens. Birds in group 4 infected with P. multocida and subsequently with $A$. galli eliminated the infection 7 weeks after the infection. There were no positive samples for P. multocida in groups 1 and 5 throughout the trial.

\subsection{Bacteriological investigation of the spleens}

All spleens sampled negative for P. multocida at the end of the trial.

\subsection{A. galli eggs, larvae and worms}

In Table 4 EPG (eggs per gram of faeces), larvae and adult worm counts are shown. Fecundity (EPG/adult female worm) and percentage of infected chickens are also given. Parasites were only recorded in the A. galli infected groups, i.e. groups 1, 3 and 4 . A chisquare test showed significant lower percentage of infected birds in group 3 compared to groups 1 and 4. A significant lower EPG was seen in group 4 compared to group 1 $(p<0.05)$. No differences were seen in EPG neither between groups 1 and 3 nor between

\begin{tabular}{lclccc}
\hline & $\begin{array}{l}\text { Group 1: } \\
\text { A. galli }\end{array}$ & $\begin{array}{l}\text { Group 2: } \\
\text { P. multocida }\end{array}$ & $\begin{array}{l}\text { Group 3: } \\
\text { A.galli } \\
+ \text { P. multocida }\end{array}$ & $\begin{array}{l}\text { Group 4: } \\
\text { P. multocida } \\
+ \text { A.galli }\end{array}$ & $\begin{array}{l}\text { Group 5: } \\
\text { control }\end{array}$ \\
\hline EPG & $652.6 \pm 802.0$ & - & $676.7 \pm 845.1$ & $137.5 \pm 232.8^{*}$ & - \\
Larvae & $0.6 \pm 1.3$ & - & $0.2 \pm 0.6$ & $0.2 \pm 0.7$ & - \\
Female worms & $4.4 \pm 5.4$ & - & $4.2 \pm 1.1$ & $2.1 \pm 2.4$ & - \\
Male worms & $1.6 \pm 2.5$ & - & $1.4 \pm 0.6$ & $1.2 \pm 2.4$ & - \\
Larvae + worms & $6.6 \pm 7.4$ & - & $5.9 \pm 5.9$ & $3.6 \pm 4.7$ & - \\
Fecundity (EPG/females) & $178.0 \pm 2480$ & - & $90.0 \pm 123.0$ & $61.0 \pm 97.0$ & - \\
Percentage infected chickens & 100 & - & $79^{*}$ & 94 & - \\
\hline
\end{tabular}

\footnotetext{
* Significantly lower $(p<0.05)$.
} 
Table 5

Total number of chickens (in \%) with pathological findings at end of experiment

\begin{tabular}{|c|c|c|c|c|c|}
\hline & $\begin{array}{l}\text { Group 1: } \\
\text { A. galli }\end{array}$ & $\begin{array}{l}\text { Group 2: } \\
\text { P. multocida }\end{array}$ & $\begin{array}{l}\text { Group 3: } \\
\text { A. galli } \\
+ \text { P. multocida }\end{array}$ & $\begin{array}{l}\text { Group 4: } \\
\text { P. multocida } \\
+ \text { A. galli }\end{array}$ & $\begin{array}{l}\text { Group 5: } \\
\text { control }\end{array}$ \\
\hline Poor body condition & - & - & $1(5)$ & $1(5)$ & - \\
\hline Dehydrated & - & - & - & $1(5)$ & - \\
\hline Pneumonia/lung necrosis & - & $5(25)$ & $4(20)$ & $3(15)$ & - \\
\hline Pleuritis & - & $3(15)$ & $2(10)$ & $1(5)$ & - \\
\hline Aerosacculitis & - & - & - & $1(5)$ & - \\
\hline Liver necrosis & - & $4(20)$ & - & - & - \\
\hline Spleen necrosis & - & $3(15)$ & - & $1(5)$ & - \\
\hline Uremia & - & - & $1(5)$ & - & - \\
\hline Peritonitis & - & - & - & - & $1(5)$ \\
\hline Bursitis presternalis & - & - & - & - & $1(5)$ \\
\hline Not in lay & - & $1(5)$ & $4(20)$ & $1(5)$ & - \\
\hline Mortality due to $P$. multocida & - & $3(15)$ & $6(30)$ & $3(15)$ & - \\
\hline $\begin{array}{l}\text { Total number of chickens } \\
\text { with pathological changes }\end{array}$ & $0 / 20(0)$ & $5 / 17(29)$ & $8 / 14(57)^{*}$ & $4 / 17(23)$ & $2 / 20(10)$ \\
\hline
\end{tabular}

* Significantly more chickens with pathological changes compared to other groups $(p<0.05)$.

groups 3 and $4(p>0.05)$. Statistical significantly differences between groups 1,3 and 4 in larvae or worms were not shown $(p>0.05)$. Neither were significant changes in fecundity seen with $t$-test $(p>0.05)$ although a trend showed lower fecundity in groups 3 and 4 .

\subsection{Pathological changes}

Table 5 shows the pathological lesions observed at the end of the experiment. Lesions were seen in the three groups infected with $P$. multocida. In the double infected group 3 significantly more chickens had pathological lesions compared to the group only infected with $P$. multocida. No pathological lesions due to $P$. multocida were observed in the A. galli group or the control group.

\section{Discussion and conclusions}

A pronounced effect of concurrent infections with $P$. multocida and A. galli was observed on weight gain, egg production, differential counts, excretion of P. multocida, parasitic findings at post-mortem and pathological changes.

Clinical signs associated with the P. multocida infected groups included depression, anorexia, ruffled feathers and mortality as the main features as reported previously by Rhoades (1964), Nagi et al. (1990) and Petersen et al. (2001) and was apparently not enhanced by the parasitic infection. The A. galli group and the control group showed, as expected, no clinical signs. Low level infections with $A$. galli may not cause clinical symptoms as reported by Permin et al. (1998b). Mortality occurred in the three groups infected with $P$. multocida, but no statistical differences were seen between the groups. 
The observed mortality was considered low, probably due to the low P. multocida dose (Matsumoto et al., 1991; Toth and Siegel, 1993; Petersen et al., 2001). A trend however indicated that the group infected with $A$. galli followed by $P$. multocida had a higher mortality. These findings are in accordance with findings by Permin et al. (2002) who demonstrated that chickens infected with $E$. coli and A. galli reacted more severely compared to chickens only infected with $E$. coli.

Weight gain was depressed in the group infected with $P$. multocida as a single infection and in the two groups additionally infected with A. galli either as a primary or secondary infection. Acute $P$. multocida infections are known to cause anorexia and subsequent weight depression as it has also been described for A. galli (Rhoades, 1964; Ikeme, 1971; Nagi et al., 1990; Permin et al., 1998a). The two double infected groups never reached a weight as high as the other groups, and at the end of the experiment especially the weight gain of the group first infected with A. galli and subsequently with $P$. multocida was lower compared to all the other groups. This could be due to an immune suppressive effect of A. galli supporting the establishment of $P$. multocida in the host (Roepstorff et al., 1999).

All groups started laying within 1-3 days after infection, e.g. at the age of 19 weeks, indicating that neither of the infections had an impact on point of lay (Anon., 2001). Significantly fewer eggs were laid per hen per week in the groups infected with $P$. multocida compared to the A. galli group and the control group. This indicates that the acute $P$. multocida infection had a negative effect on the egg production which is in accordance with previous observations (Campi et al., 1990). Infections with A. galli may decrease egg production in layers (Permin et al., 1998a); however, the missing effect observed in this study might be related to the relatively high age of chickens when infected (Kerr, 1955).

In the double infected groups the percentage of lymphocytes were significantly lower compared to the A. galli and the control groups. These results suggest that the immune system was depressed in double infected groups compared to groups only infected with one pathogen and the control group. Furthermore, the results indicate that a primary A. galli infection followed by a secondary $P$. multocida infection affect the birds more seriously than a single bacterial infection. When the birds are infected with $P$. multocida first and A. galli last, an inhibiting effect on the immune system may be seen, but it cannot be distinguished from a single bacterial infection, underlining that the order of multiple infections might have an important impact on the outcome. Likewise the double infected groups had higher heterophilic counts compared to the other groups suggesting that the parasitic infection enhances the heterophilic response. The double infected groups did not seem to have an eosinophilic reaction towards the parasites as they did not distinguish themselves from the control group, whereas the A. galli infected group had a significantly higher eosinophilic count coincident with the prepatent time of A. galli (Kerr, 1955; Ikeme, 1971; Permin et al., 1998b).

A decreasing number of $P$. multocida carriers was seen in all P. multocida infected groups during the experiment. However, chickens in groups 2 and 3 did not clear themselves totally for the infection as the birds in group 4. An infection dose of approximately $10^{4} \mathrm{cfu}$ per chicken is considered low (Matsumoto et al., 1991; Toth and Siegel, 1993). The low infections dose was chosen to allow us study the epidemiology 
of $P$. multocida in relation to $A$. galli infections. $P$. multocida carriers were observed even 10 weeks after inoculation, especially in the group primary infected with A. galli. Under free range conditions, where parasitic infections always are present (Permin et al., 1998b), chickens remain carriers of $P$. multocida for a longer period, having epidemiological implications. Cannibalism (i.e. stress) seems to have a similar effect on the carrier status of P. multocida infected chickens (Permin et al., unpublished results).

At the end of the experiment none of the spleens tested positive for $P$. multocida. This is in agreement with previous studies by Petersen et al. (2001) who showed that $P$. multocida was eliminated from the spleens of chickens within $48 \mathrm{~h}$. In contrast, all A. galli infected groups harboured larval and adult stages of A. galli at slaughter. Significantly fewer chickens were infected in the group first infected with $A$. galli and subsequently with P. multocida. Generally, the establishment rate in individual chickens depends on the size of the infection dose (Ackert et al., 1931; Permin et al., 1997a). Furthermore, in experimental and natural infections all chickens become infected (Permin et al., 1998b, 1999). The reason for some of the animals being negative in this study is not known, but might possibly be related to a cross-over effect of the concurrent infection. A recent paper by Pritchard and Brown, 2001 has indicated that although cellular response mechanisms of bacteria and parasites are related to each their pathway (Th2 for parasites and Th1 for bacteria) there is a balance between the two pathways. Thus a parasite infection might favour the Th2 cell development and indirectly suppress the establishment of bacteria or vice versa. A significantly lower EPG was observed in the group infected first with $P$. multocida and then with $A$. galli. This could imply that $P$. multocida has a suppressive effect on the livelihood and establishment of the parasite, since a trend showing a lower worm burden in this group was observed. This might also be explained as a result of an enhanced immune defence triggered by the $P$. multocida infection.

Significantly more birds were observed with pathological lesions in the group first infected with $A$. galli and subsequently with $P$. multocida. This might be a result of an inhibited defence system in the birds first infected with the parasite, facilitating the establishment of bacteria in the host (Pritchard and Brown, 2001).

Health aspects are rarely discussed in relation to welfare of free range chickens (Craig and Swanson, 1994). However, free range chickens are often subclinically infected with A. galli (Matter and Oester, 1989; Permin et al., 1998b, 1999) and P. multocida (Christensen et al., 1998). It is therefore postulated that free range chickens are at higher risk of being subjected to serious outbreaks of fowl cholera when they are permanently infected with A. galli. The fact that poultry in organic systems are not treated against gastrointestinal parasites contributes to this postulation.

In conclusion a negative interaction between A. galli and P. multocida was observed. Combined infections had a more severe effect on the birds compared to single infections for reasons which remains to be investigated. Carrier animals were also common in this group. Even a subclinical $A$. galli infection seems to enhance the establishment of $P$. multocida. If $A$. galli represents a secondary infection, the clinical picture was quite equal to that of the single $P$. multocida infection. However, $P$. multocida affected A. galli establishment. Since multiple infections are common under non-confined conditions basic studies on interaction of infections are greatly needed. Understanding the mechanisms behind the interactions will improve the possibilities of prevention. 


\section{Acknowledgements}

We would like to thank Rikke Frahm Lundvig, Pernille Ginsbo, Pia Mortensen, Stina Holm, Niels Midtgaard, Jørgen Olesen, Johnny Jensen, Thomas Bernau Kristensen and Rene Bülow for technical assistance during the experiment. Financial support by the Council for Development Research (Danida) through the project "Multiple infections in free range poultry" is highly appreciated.

\section{References}

Ackert, J.E., Graham, G.L., Nolf, L.O., Porter, D.A., 1931. Quantitative studies on the administration of variable numbers of nematode eggs (Ascaridia lineata) to chickens. Trans. Am. Microsc. Soc. 50, 206-214.

Adedeji, S.O., Ogunba, E.O., Dipeolu, O.O., 1989. Synergistic effect of migrating Ascaris larvae and Escherichia coli in piglets. J. Helminthol. 26, 17-32.

Anon., 2000. The Danish Poultry Council. Statistics on www.poultry.dk.

Anon., 2001. Layer Management Program. Lohmann Brown. Lohmann Tierzucht.

Campi, T.W., Carpenter, T.E., Hird, D.W., Snipes, K.P., Hirsh, D.C., 1990. Fowl cholera in California multiplier breeder turkeys: 1985-1986. Avian Dis. 34, 928-933.

Christensen, J.P., Dietz, H.H., Bisgaard, M., 1998. Phenotypic and genotypic characters of isolates of Pasteurella multocida obtained from back-yard poultry and from two outbreaks of avian cholera in avifauna in Denmark. Avian Pathol. 27, 373-381.

Christensen, J.P., Petersen, K.M.D., Hansen, H.C., Bisgaard, M., 1999. Forekomst af fjerkrækolera i dansk avifauna og fjerkræproduktion-mulige smittemæssige sammenhænge. Dansk Vet. Tidsskr. 82, 342-346.

Craig, J.V., Swanson, J.C., 1994. Review: welfare perspectives on hens kept for egg production. Poult. Sci. 73, 921-938.

Ikeme, M.M., 1971. Effects of different levels of nutrition and continuing dosing of poultry with Ascaridia galli eggs on the subsequent development of parasite populations. Parasitology 63, 233-250.

Kerr, K.B., 1955. Age of chickens and the rate of maturation of Ascaridia galli. J. Parasitol. 41, $233-235$.

Matsumoto, M., Strain, J.G., Engel, H.N., 1991. The fate of Pasteurella multocida after intratracheal inoculation into turkeys. Poult. Sci. 70, 2259-2266.

Matter, F., Oester, H., 1989. Hygiene and welfare implications of alternative husbandry systems for laying hens. In: Faure, J.M., Mills, A.D. (Eds.), Proceedings of the Third European Symposium on Poultry Welfare, Tours, France.

Muhairwa, A.P., Christensen, J.P., Bisgaard, M., 2000. Investigations on the carrier rate of Pasteurella multocida in healthy commercial poultry flocks and flocks affected by fowl cholera. Avian Pathol. 29, 133-142.

Nagi, A.A., Youssef, M.S., Mousa, S., Bayoumi, A.H., 1990. Clinico-pathological and bacteriological studies on avian pasteurellosis. Assiut Vet. Med. J. 22, 88-94.

Permin, A., Hansen, J.W., 1998. Epidemiology, Diagnosis and Control of Poultry Parasites. Food and Agriculture Organization of the United Nations, Rome, Italy, pp. 74-105, 111-115.

Permin, A., Bojesen, M., Nansen, P., Bisgaard, M., Frandsen, F., Pearman, M., 1997a. Ascaridia galli populations in chickens following single infections with different dose levels. Parasitol. Res. 83, 614-617.

Permin, A., Pearman, M., Nansen, P., Bisgaard, M., Frandsen, F., 1997b. An investigation on different media for embryonation of Ascaridia galli eggs. Helminthologia 34, 75-79.

Permin, A., Nansen, P., Bisgaard, M., Frandsen, F., 1998a. Ascaridia galli infections in free range layers fed different levels of protein. Brit. Poult. Sci. 39, 441-445.

Permin, A., Nansen, P., Bisgaard, M., Frandsen, F., 1998b. Investigations on the infection and transmission of Ascaridia galli in free range chickens kept at different stocking rates. Avian Pathol. 27, 382-389.

Permin, A., Bisgaard, M., Frandsen, F., Pearman, M., Nansen, P., Kold, J., 1999. The prevalence of gastrointestinal helminths in different poultry systems. Brit. Poult. Sci. 40, 439-443.

Permin, A., Christensen, J.P., Bisgaard, M., 2002. Consequences of concurrent Ascaridia galli and Escherichia coli infections in chickens. Avian Pathol., in press. 
Petersen, K.M.D., Christensen, J.P., Permin, A., Bisgaard, M., 2001. Virulence studies in domestic and freeliving birds of a clone of Pasteurella multocida ssp. multocida obtained from an outbreak of fowl cholera in wild birds. Avian Pathol. 30, 27-31.

Pritchard, D.I., Brown, A., 2001. Is Necator americanus approaching a mutualistic symbiotic relationship with humans? Trends Parasitol. 17, 169-172.

Rhoades, K.R., 1964. The microscopic lesions of acute fowl cholera in mature chickens. Avian Dis. 8, 658-665.

Roepstorff, A., Nørgaard-Nielsen, G., Permin, A., Simonsen, H.B., 1999. Male behaviour and male hormones in Ascaridia galli infected hens. In: Proceedings of the XIX Symposium of the Scandinavian Society for Parasitology, Iceland, May 8-11.

Thrusfield, M., 1995. Veterinary Epidemiology, 2nd Edition. Blackwell Science Publications, Oxford.

Toth, T.E., Siegel, P.B., 1993. Cellular defence of the avian respiratory system: dose-response relationship and duration of response in intratracheal stimulation of avian respiratory phagocytes by a Pasteurella multocida bacterin. Avian Dis. 37, 756-762.

Wade, W.F., Gaafar, S.M., 1981. Effects of salmonellosis on subsequent infections with Ascaris suum in swine. Vet. Parasitol. 8, 309-317. 